\title{
Sheffield \\ Hallam \\ University
}

\section{Integrated management of ash from industrial and domestic combustion : a new sustainable approach for reducing greenhouse gas emissions from energy conversion}

BENASSI, L, DALIPI, R, CONSIGLI, V, PASQUALI, M, BORGESE, L, DEPERO, L E, CLEGG, Francis <http://orcid.org/0000-0002-9566-5739>, BINGHAM, Paul <http://orcid.org/0000-0001-6017-0798> and BONTEMPI, E Available from Sheffield Hallam University Research Archive (SHURA) at: http://shura.shu.ac.uk/15844/

This document is the author deposited version. You are advised to consult the publisher's version if you wish to cite from it.

\section{Published version}

BENASSI, L, DALIPI, R, CONSIGLI, V, PASQUALI, M, BORGESE, L, DEPERO, L E, CLEGG, Francis, BINGHAM, Paul and BONTEMPI, E (2017). Integrated management of ash from industrial and domestic combustion : a new sustainable approach for reducing greenhouse gas emissions from energy conversion. Environmental Science and Pollution Research, 24 (17), 14834-14846.

Copyright and re-use policy

See http://shura.shu.ac.uk/information.html 
Integrated management of ash from industrial and domestic combustion: a new sustainable approach for reducing greenhouse gas emissions from energy conversion

Laura Benassi ${ }^{1}$, Rogerta Dalipi ${ }^{1}$, Veronica Consigli ${ }^{1}$, Michela Pasquali ${ }^{1}$, Laura Borgese ${ }^{1}$, Laura E. Depero ${ }^{1}$, Francis Clegg ${ }^{2}$, Paul A. Bingham ${ }^{2}$, Elza Bontempi ${ }^{1, *}$

${ }^{1}$ INSTM and Chemistry for Technologies Laboratory, University of Brescia, via Branze 38, 25123 Brescia, Italy

${ }^{2}$ Materials and Engineering Research Institute, Sheffield Hallam University, Howard Street, Sheffield, S1 1WB, $U K$

*Corresponding author: Elza Bontempi, e-mail: elza.bontempi@unibs.it; Tel: +39030 3715573

To the memory of Serena Sganzerla

\section{Acknowledgments}

This study was supported by LIFE+, the financial instrument of the European Community to support environmental projects (LIFE+ 2011 project ENV/IT/000256). This activity was realized in the frame of MINEA (Mining the European Anthroposphere) COST Action. 


\begin{abstract}
This work supports, for the first time, the integrated management of waste materials arising from industrial processes (fly ash from municipal solid waste incineration and coal fly ash), agriculture (rice husk ash) and domestic activities (ash from wood biomass burning in domestic stoves). The main novelty of the paper is the reuse of wood pellet ash, an underestimated environmental problem, by the application of a new technology (COSMOS-RICE), that already involves the reuse of fly ashes from industrial and agricultural origins. The reaction mechanism involves carbonation: this occurs at room temperature and promotes permanent carbon dioxide sequestration. The obtained samples were characterized using XRD and TGA (coupled with mass spectroscopy). This allowed quantification of the mass loss attributed to different calcium carbonate phases. In particular, samples stabilized using wood pellet ash show a weight loss, attributed to the decomposition of carbonates greater than 20\%. In view of these results, it is possible to conclude that there are several environmental benefits from wood pellet ash reuse in this way. In particular, using this technology, it is shown that for wood pellet biomass the carbon dioxide conversion can be considered negative.
\end{abstract}

Keywords: waste; pellet ash reuse; rice husk ash; COSMOS-RICE, $\mathrm{CO}_{2}$ sequestration, sustainability 


\section{Introduction}

Today waste incineration represents a necessity for the sustainable management of European solid wastes (Xingang et al., 2016). However, while modern waste incineration represents a consolidated technology for volume and waste mass reduction, combined with efficient energy recovery, an important amount of ash originates from combustion. Final solid residues are around $30 \%$ of the total mass input. Moreover, these residues can be divided into bottom and fly ash (Zacco et al., 2014). Whilst bottom ash is already reused as, for example, additives for construction materials (Mehta and Siddique, 2016), fly ash is generally disposed of in landfills because it represents a danger to the environment and human health (Guarienti et al., 2014). Municipal solid waste incineration (MSWI) fly ash comprises higher concentrations of heavy metals than bottom ash, and it therefore requires treatment to make it environmentally safe before disposal.

To safely handle and dispose of MSWI fly ash, several methods have been proposed. At present, separation processes, solidification/stabilization $(\mathrm{S} / \mathrm{S})$ and thermal treatments are the three main techniques used (Zacco et al., 2014). Separation methods are usually conducted to reduce the levels of chloride, other salts (such as sulphate, bromine and iodine), alkalis and heavy metals. For example, washing in water is a feasible method to remove chlorides and salts from ash. However, large amounts of heavy metals are released with the soluble salts (Colangelo et al., 2012) making this less a desirable process route.

S/S methods refer to technologies that use additives (or binders) to physically and/or chemically immobilize hazardous constituents in fly ash (Zacco et al., 2014). Addition of ordinary portland cement (OPC) for solidification is the most popular approach. Thermal treatments, that-which are energy intensive, are usually applied for fly ash reuse, and are mainly done carried out by sintering, melting, or vitrification (Zacco et al., 2014).

In the last few years a new technology for MSWI fly ash stabilization has been developed (Bontempi et al., 2010a) and optimized (Bosio et al., 2013, 2014). This technology is based on the use of a source of reactive amorphous silica and a source of calcium hydroxide. Amorphous silica reacts with leachable heavy metals allowing stable silicates phases $\left(\mathrm{PbSiO}_{3}\right.$ and $\left.\mathrm{Zn}_{2} \mathrm{SiO}_{4}\right)$ to be obtained, as confirmed shown by $\mathrm{X}$-ray absorption spectroscopy (Struis et al., 2013). Calcium hydroxide contributes to fly ash carbonation, with the probable formation of immobile metal carbonates as an additional mechanism of metal entrapment (Bosio et al., 2014). Originally the amorphous silica source was provided by commercial colloidal silica. Recently the process was optimized,-in order to use silica by-products, such as silica fume (Rodella et al. 2014) and rice husk ash (RHA), an agricultural waste (COSMOS-RICE project). The calcium hydroxide source was always provided by flue-gas desulfurization (FGD) residues. The process is sustainable, because it is carried out at low temperatures and employs only water, by-products and wastes generated from industrial energy conversion processes. Indeed, despite that Although also other recently proposed technologies use by-products and wastes for heavy metals stabilization in MSWI fly ash, they also use commercial chemicals are employed in the processes-and are therefore less sustainable and less economically viable (Ye et al., 2016). Another advantage of the proposed technology, in contrast to classical stabilization/solidification treatments, is that the final stabilized material is a powder, that could potentially-ean be reused as a raw material in other applications, for example as a filler material.

This aim of this work was to build on the success of previous work (COSMOS-RICE) and to investigate the employment of a different ash typology in the stabilization procedure: i.e. biomass ash. Indeed, iIn recent years 
EU policy has pushed tosupported increasing the demand for renewable energy sources. This is because it is widely accepted that the production and use of biofuels can contribute to the net reduction of greenhouse gas emissions (Katers et al., 2012), due to their close-to-neutral carbon emission (Sjølie and Solberg, 2011, Hansson and Hackl, 2016). By switching from coal and natural gas to biomass, the net $\mathrm{CO}_{2}$ emission per unit heating value can be reduced by $93 \%$ and $84 \%$, respectively (Niu et al., 2016).

Among the different existing typologies of biomass, the use of pelletized fuels is are-one of the most widespread because they pelletized fuels show better characteristics than advantages over other biomass products, such as chips and briquettes, especially concerning due to their higher density and uniform dimensions. In particular, pellets of wood, such as beech or spruce, and straw, present lower ash contents and higher heat contents than most waste-derived pellets (Arranz et al., 2015).

To better define and describe the modification of the COSMOS-RICE technology, the pellet wood ash must first be properly characterized. Unfortunately, detailed and complete data sets from simultaneous chemical and phase-mineral analyses for wood pellet solid combustion products are scarce. Some studies have used data from the ash yield of biomass or the bulk chemical composition of ash to define mineral composition, but this is not ideal and can lead to confusion (Vassilev et al., 2013b).

A recent review article (Vassilev et al., 2013b), reports results from biomass ash compositional analysis. It shows that phases and minerals generally identified in biomass ash include approximately 291 species, in contrast to 188 species found in coal ash. Despite this, there is no specific data for only wood pellet ash, although the review reports that biomass ash from wood generally contains carbonates, glass, silicates, oxyhydroxides, and some sulfates and phosphates. Most of these phases are not normally identified in coal ashes, because of the enrichment of elements such as $\mathrm{Ca}, \mathrm{Cl}, \mathrm{K}, \mathrm{Mg}, \mathrm{Mn}, \mathrm{Na}$ and $\mathrm{P}$ in biomass ash compared to coal ash.

There is, in some literature, the inaccurate presumption that biomass combustion systems are non-polluting or that biomass ash does not contain toxic metals (Ahmaruzzaman, 2010). Indeed, literature shows that this ash can contain carcinogenic and mutagenic polycyclic aromatic hydrocarbons (Orecchio et al., 2016). Additionally, in biomass ash, heavy metals tend to occur in much more mobile and hazardous compounds than in coal ash (Loo et al., 2002; Steenari et al., 1999, Niu et al., 2016). Unfortunately, systematic studies of the concentration, modes of occurrence, behavior and fate of hazardous phases and trace elements in biomass fuels and their ashes are only at an initial stage of investigation (Vassilev et al., 2013a). MoreoverIn contrast, the stabilization technology proposed inthis-the work presented here is able to stabilize heavy metals, if eventually present in the wood pellet ash.

The limited available literature data concerning biomass ash compositions (Niu et al., 2016) suggests that it ean could potentially be employed in the COSMOS-RICE stabilization technology. In particular, due to their composition, flue-gas desulfurization (FGD) residues, by-products generated by air pollution control equipment in coal-fired power plants to reduce atmospheric sulphur release, appear to be the best candidate that can be substituted by wood pellet ash. This provided the rationale for the present study.

The new stabilized material obtained from the COSMOS-RICE procedure has two advantages: it can sequestrate $\mathrm{CO}_{2}$ and it can be employed as a partial or full substitute of some "critical "raw materials" (Besco et al., 2013, 2014; Ponsot et al., 2015; Zaceo et al., 2012) for example-in plastics and ceramics composites. Carbon capture and storage (CCS) is one approach that has been proposed for $\mathrm{CO}_{2}$ mitigation from stationary sources 
(Siefert and Litster, 2013). Moreover, $\mathrm{CO}_{2}$ capture/separation is a critical step due to its-the low Technology Readiness Levels (TRL's) of the presently-available technologies,technical feasibility and their relatively high costs (Ridha et al., 2015). Indeed, previously-proposed technologies, for post-combustion $\mathrm{CO}_{2}$ capture; require treatment at high temperatures and the employment of a material, i.e. calcium oxide $(\mathrm{CaO})$, that generally must be regenerated. This oxy-combustion imposes an energy penalty (due to the consumption of fuel and oxygen) and generates additional $\mathrm{CO}_{2}$ (Valverde et al., 2015; De et al., 2015). We have recently shown that the stabilized material obtained by means of COSMOS-RICE technology has a $\mathrm{CO}_{2}$ sequestration capability of approximately $95 \mathrm{~g} / \mathrm{Kg}$ (Bosio et al., 2014).

In this work, for the first time, the opportunity of mixing several waste materials, with ash from biomass, without the addition of any commercial chemical, is presented. This article investigates the synergic effect due to the use of waste ash materials, but from different sources (industrial, agricultural, and domestic). In particular, industrial toxic fly ash (from MSWI), containing leachable heavy metals, is the major component (at $65 \%$ ) used in the mixture, but the addition of biomass and agricultural ashes is necessary for the chemical stabilization of the leaching metals. The aim of this article is not only to shown that the obtained material, after the stabilization procedure, is safe and stable, but also that it can be re-employed as new material. In particular, it may be possible to re-used-the materials generated by this treatment, for example as a filler for severat material in a number of potential applications, reducing the requirement for virgin raw materials and helping to progress towards more sustainable societies. The concept of reusing valuable materials contained in toxic fly ash has already been discussed in the literature (Funari et al., 2015). However, the available articles on this subject are mainly devoted to the recovery of precious metals and earth elements that represent a limited content in these ashes. On the contraryHere, for the first time, the present work shows that the opportune mixing of different fly ashes allows to enables obtaining a valuable new material, with the complete recovery of all ashes. In particular, considering the-active MSWI plants in the European Union (EUROSTAT, 2013), the annual total amount of resulting stabilized material from industrial fly ash may be approximately 2.9 million tons. This process can potentially improve the closure of symbiotic industrial cycles by reusing $100 \%$ of the produced ashes, for example in the plastic composites sector. Finally, this work also evaluates the contribution of the proposed technology to greenhouse gas emissions.

\section{Materials and Methods}

Stabilized samples were prepared from MSWI fly ash (provided by an Italian grate firing incinerator and containing leachable metals) by adding other waste materials: coal fly ash, RHA, and wood pellet ash.

All samples were prepared following the same protocol, i.e. by wetting a mixture of $200 \mathrm{~g}$ of the three powders: MSWI fly ash, wood pellet ash, coal fly ash (in the relative weight percent: $65 \%, 20 \%$ and $15 \%$ ) and $20 \mathrm{~g}$ of RHA with $300 \mathrm{~g}$ of water, and stirring for 30 minutes in a laboratory mixer at $100^{\circ} \mathrm{C}$ (Bontempi, 2012). Five different wood pellet samples were purchased on the Italian market, burned combusted to completion in domestic wood stoves and used to obtain 5 different wood pellet-based ash samples via the stabilization process.

A reference sample was also prepared using allthe same powders, but substitung replacing the wood pellet ash with FGD residues (Bosio et al., 2013, 2014). FGD residue is the main by-product of the desulfurization system used to remove $\mathrm{SO}_{\mathrm{x}}$ from coal combustion products. This is not considered a waste, however, it is generally it is stored. The use of FGD residue represents a previously tested stabilization procedure that was 
established in the COSMOS-RICE project (COSMOS-RICE). Afterwards the residual water present in samples was evaporated at room temperature (approximately $21^{\circ} \mathrm{C}$ ). Thirty days later all samples were completely dried.

After chemical stabilization of heavy metals, the solid inertized material can be washed to recover almost pure soluble salts (Bontempi et al., 2010a). In the present case, salt recovery was not realized. Leaching tests were performed according to the CEN normative (Europe, 2002 CEN 2002), in order to quantify the leachability of heavy metals from the products in water. The contact time of materials and aqueous solution was $2 \mathrm{~h}$, a time sufficient to establish equilibrium in subsequent experiments with MSWI fly ash (Yang et al., 2009). Leaching tests were performed when samples were completely dried (i.e. 30 days after treatment, which corresponds to week 5 in Tables 3 and 4). The same test was repeated after-one, two, three and four weeks later-after the first test, to verify the materials stability. At all times, samples were stored in air in a laboratory at room temperature.

Wood pellets and corresponding ash samples were digested in acid solution for chemical composition analysis by means of a CEM Discover Microwave oven. Samples were prepared using $0.18 \mathrm{~g}$ of sample material in a solution of $Z 4 \mathrm{ml} \mathrm{HNO}_{3}(65 \mathrm{vol} . \%), 2 \mathrm{ml} \mathrm{HF}$ (47 vol.\%) and $2 \mathrm{ml} \mathrm{HCl}$ (37 vol.\%) (Instrument parameters: temperature $210^{\circ} \mathrm{C}$, time 9 min, power $300 \mathrm{~W}$, medium stirring).

Glass containers were covered with commercially available teflon cups, designed on purpose for HF involving procedures. After digestion a small amount of solid particles, visible at the naked eye, was present at the bottom of the container. The suspension was carefully shaked and added with Ga, to be used as internal standard, in concentration $1 \mathrm{mg} / \mathrm{l}$ (Borgese et al., 2009). Elemental chemical analysis of the leachate solution was carried out using Total Reflection X-Ray fluorescence (TXRF) with a Bruker S2 Picofox (air cooled, Mo tube, Silicon-drift detector), with operating parameters of $50 \mathrm{kV}$ and $750 \mu \mathrm{A}$. An aliquot of $10 \mu \mathrm{l}$ of the suspension was directly pipetted on plexiglass discs used as sample carriers. All work was performed under a fume hood. The life time of TXRF measurements was using an acquisition time of 600 seconds. TXRF quantitative analysis of the suspended samples was performed using the internal standard procedure. An appropriate amount of gallium, used as an internal standard element, was added (Borgese et al., 2009).

X-Ray Diffraction (XRD) measurements were performed with Panalytical X'Pert Pro diffractometer equipped with the $\mathrm{X}^{\prime}$ Celerator detector and $\mathrm{Cu}$ anode. Operating values were $40 \mathrm{kV}$ and $40 \mathrm{~mA}$. Thermogravimetric analyses (TGA) were performed using a TGA/DSC Star System manufactured by Mettler Toledo. Approximately $10 \mathrm{mg}$ of each sample was heated in alumina crucible from $35-1000^{\circ} \mathrm{C}$ at a heating rate of $10^{\circ} \mathrm{C} \min ^{-1}$ under an air flow of $40 \mathrm{ml} \mathrm{min}^{-1}$. Thermogravimetric-Mass Spectrometry (TG-MS) measurements were carried out using a Netzsch Simultaneous Thermal Analyser 409 PG Luxx, which is coupled to an Aëolos mass spectrometer via a heated capillary transfer line. Transfer lines and adapter heads were heated to $180^{\circ} \mathrm{C}$. The heating rate was $10^{\circ} \mathrm{C} \mathrm{m^{-1 }}$ and the temperature range was $35-1100^{\circ} \mathrm{C}$. Air was used as flue gas with a flow rate of $40 \mathrm{ml} \mathrm{min}^{-1}$. Alumina crucibles were used to contain about $20 \mathrm{mg}$ of sample.

\section{Results and Discussion}

\section{Results}

Tables 1 and 2 respectively show the elemental compositions of wood pellet samples (A, B, C, D, and E) before and after combustion. It is evident that the -metal concentrations increase after pellet burning, due to the combustion of the organic part-fraction of the material. In addition, some metals that were present at undetectable concentrations in the wood pellets can be detected in the respective ashes $(\mathrm{Sr}, \mathrm{Ba}$, and $\mathrm{Pb})$ after 
combustion. The data in Table 2 is very-variable; this variability probably arising from compositional differences between different wood pellets. However, for all samples, the elements present in the highest quantities in the ashes obtained from combustion are $\mathrm{K}, \mathrm{Ca}, \mathrm{Mn}$ and $\mathrm{Fe}$.

XRD patterns collected from all pellet ashes are reported in Fig. 2. It is very-important to highlight- note that whilst XRD enly-detects and identifies crystalline phases, it is more difficult to detect and identify amorphous phases, although amorphous phases these do exhibit broad peaks often described as "amorphous humps". Although some articles report ash-compositions of wood pellets ash, these theyare only derived from elemental chemical analysis, and from which their corresponding oxides are attributed (for example $\mathrm{Ca}$ is expected to form $\mathrm{CaO}$ and so on) (Arranz et al., 2015). As a consequence, it is not possible to directly compare data in the literature with that reported in Fig. 2, specifically concerning the phase composition of wood biomass ash. XRD therefore offers additional phase composition, which is essential to fully understand their chemical behavior of these ashes. The confirmed presence of $\mathrm{CaO}$ in all samples supports the decision to use wood biomass ash to substitute FGD residues, the source of calcium hydroxide in the process.

Table 3 reports the results of the leaching tests made on MSWI fly ash and the samples treated using the COSMOS-RICE procedure (the stabilized wood pellet-based samples are named CR). The starting MSWI fly ash shows the important presence of leachable metals, mainly $\mathrm{Pb}$ and $\mathrm{Zn}$. The leaching experiments performed during weeks 6,7 and 8 verify that all samples are chemically stable stabilize.

Fig. 4 presents the XRD patterns collected from the wood pellet ashes and FGD residues after treatment using the COSMOS-RICE procedure. The diffraction pattern for the reference sample shows the presence of some a number of crystalline silicon oxides $\left(\mathrm{SiO}_{2}\right.$, as cristobalite and quartz), calcite $\left(\mathrm{CaCO}_{3}\right)$, sodium chloride (Halite, $\mathrm{NaCl})$, thaumasite $\left(\mathrm{Ca}_{3}\left(\mathrm{SO}_{4}\right)\left[\mathrm{Si}(\mathrm{OH})_{6}\right]\left(\mathrm{CO}_{3}\right) \cdot 12\left(\mathrm{H}_{2} \mathrm{O}\right)\right)$, and gypsum $\left(\mathrm{CaSO}_{4} \cdot 2\left(\mathrm{H}_{2} \mathrm{O}\right)\right.$. Almost the same phases are found in the samples realized with wood pellet ashes presumably due to the same reactions that involve carbonation (Bosio et al., 2014).

Table 4 summarizes the findings from the XRD patterns in terms of phases detected in the reference and wood pellet ash samples created using the COSMOS-RICE procedure and at different times corresponding to the subsequent leaching experiments reported in Table 3 (i.e. weeks 6 to 8). The phases detected in XRD patterns collected three months after the stabilization procedure (corresponding to week 13) are also included to verify sample stability.

TGA and TG-MS measurements were carried out to evaluate the amount of carbon dioxide sequestered in the CR samples and reference. DTG diagram obtained from CR samples and reference is illustrated in Fig. 5 (a). All samples exhibit similar profiles, indicating that the thermal events associated with weight loss in each sample have the similar origins. The reference sample shows a higher weight loss (TGA curves are not reported here), in comparison to all other CR samples, at temperature up to and including $120^{\circ} \mathrm{C}$, corresponding to the loss of physically-bound water. Weight loss also continues above $120^{\circ} \mathrm{C}$ in all samples. This combined lowtemperature weight loss of approximately 10 to 15 weight $\%$ at temperatures up to $400^{\circ} \mathrm{C}$ is consistent with the presence removal of physical water and evolution of chemically-bound water from several hydrated phases in these samples (see Table 4). In particular, the reference sample exhibits a larger number of hydrate phases including hydrated calcium sulfates, as evidenced by XRD, and this explains the higher levels of weight loss from the reference sample than the CR samples at these lower temperatures. 
A mass spectrometer was coupled with a thermogravimetric analyzer, in order to detect which gases $\left(\mathrm{H}_{2} \mathrm{O}\right.$, $\mathrm{CO}_{2}$ and $\mathrm{SO}_{2}$ ) are emitted during the heating process, and over which temperature ranges. The reference and $\mathrm{CR}$ samples were measured with respect to the measured emitted gases $\left(\mathrm{MW}=18\left(\mathrm{H}_{2} \mathrm{O}\right), 44\left(\mathrm{CO}_{2}\right)\right.$ and $\left.64\left(\mathrm{SO}_{2}\right)\right)$, and all samples show similar behavior, thus only the result for the reference sample is reported (Fig. 5 (b)). The only difference among the emitted gases refers to $\mathrm{MW}=64\left(\mathrm{SO}_{2}\right)$, which shows an undetectable contribution from CR samples obtained by using pellet ashes instead of FGD residues. This is because the reference sample contains gypsum and other calcium sulfate phases (Fig. 4 and Table 4).

Table 5 reports the weight loss from CR samples in selected temperatures ranges based on the type of calcium carbonate (see below for further explanation). It shows that the amount of released $\mathrm{CO}_{2}$ is extremely consistently significant for all samples.

\section{Discussion}

To establish the reuse of wood pellet ashes by the application of COSMOS-RICE technology, the first important research step concerns their characterization. Considering the wood pellet composition before and after the combustion (Table 1 and 2), it shows that $\mathrm{K}, \mathrm{Ca}, \mathrm{Mn}$ and $\mathrm{Zn}$ exhibit the largest increases most highly-in concentration in the wood pellet ash with respect to the corresponding wood pellet. In particular, the Mn concentration in wood pellets is comparable to $\mathrm{Ni}$ and As, but is greatly increased in the ashes. This result is consistent with the literature, which reports that biomass ashes are commonly enriched in $\mathrm{Mn}$ and $\mathrm{K}$ in comparison with coal ashes (Vassilev et al., 2013b).

Data in Table 1 can be compared with the values reported by (Chandrasekaran et al., 2012), corresponding to wood pellet compositions of 132 American samples. This is the first article reporting a large number of analyzed wood pellet samples, and highlights the problem of heavy metals contained in the-biomass for domestic combustion. It is interesting to note that pellet samples analyzed in this work show high concentrations of $\mathrm{As}$ and $\mathrm{Cl}$. Also the concentrations of $\mathrm{Mn}, \mathrm{Ba}$ and $\mathrm{Pb}$ found in the present work are generally higher than in data obtained by (Chandrasekaran et al., 2012). Finally, $\mathrm{Zn}$ and $\mathrm{Ni}$ are also found in samples analyzed in this work, but they were not reported in the analyses of the American wood pellets.

Fig. 1 graphically displays the results reported in Table 1 and 2, for ready comparison and identification of the enrichment due to combustion. It appears that the metals content is not uniform across the different selected wood pellet ashes (for example Ti can be found only in sample B, Cr in samples A and B), which may have been due to the properties of the original biomasses and the conditions of their cultivation. However, general trends can be highlighted in the heavy metals enrichment in the ashes. Using a logarithmic scale to display the data it is shown that the detected elements exhibit similar enrichment behavior. Moreover, the metals that display the most significant enrichment are $\mathrm{Ca}, \mathrm{K}$, and $\mathrm{Mn}$. Also $\mathrm{Zn}$ shows generally high enrichment in ashes, except for sample $\mathrm{E}$. $\mathrm{Pb}, \mathrm{Ru}, \mathrm{Sr}$ and $\mathrm{Ba}$, that generally cannot be detected in wood pellets, are present in relatively high quantities in the corresponding ashes (up to around $1000 \mathrm{mg} / \mathrm{Kg}$ ).

In Fig. 2, which reports XRD patterns collected on all wood pellet ashes, some halos are present in the range $28-36^{\circ}(2 \theta)$, which indicatesare consistent with the presenceeceurrence of amorphous phases. It is interesting to note that all diffraction patterns show the presence of calcium oxide, calcite and magnesium oxide, in agreement with (Vassilev et al., 2013b). The ash composition is variable for some other phases: samples A and $\mathrm{C}$ contain also quartz; samples $\mathrm{B}, \mathrm{C}, \mathrm{D}$ and $\mathrm{E}$ contain also potassium calcium carbonate $\left[\mathrm{K}_{2} \mathrm{Ca}\left(\mathrm{CO}_{3}\right)_{2}\right]$; 
samples B, D and E contains also calcium phosphate hydroxide $\left[\mathrm{Ca}_{5}\left(\mathrm{PO}_{4}\right)_{3}(\mathrm{OH})\right]$; sample A contains also potassium chloride (Sylvite, $\mathrm{KCl}$ ); and samples $\mathrm{C}$ and $\mathrm{E}$ contain also potassium sulfate $\left(\mathrm{K}_{2} \mathrm{~S}_{2} \mathrm{O}_{7}\right)$. All of these phases are known to occur in biomass ash (Vassilev et al., 2013b). Finally, all samples show the presence of an unexpected phase: calcium manganese oxide $\left(\mathrm{Ca}_{2} \mathrm{Mn}_{2} \mathrm{O}_{5}\right)$. This phase, which is consistent with elemental data reported in Table 2, was not previously reported in biomass ashes. before. Previously, the presence of Mn has been generally attributed to the formation of manganese containing phases in ash from biomass (Mellbo et al., 2008) or more generally to Mn enrichment (Vassilev et al., 2013b). Unfortunately, the lack of data for wood pellet biomass ash compositions does not allow further a more detailed consideration of this phase.

Since biomass contains significant amounts of flame-volatile alkali metal salts, it can contribute more strongly to the corrosion of the boilers more strongly than fossil fuels (Niu et al., 2016). In particular, it was reported that heavy metal compounds can significantly decrease the melting point of a deposit, and thus the corrosion caused by molten salts (as for example chlorides) can be of great importance (Bankiewicz et al., 2009). The presence of such a high content of Mn in ash should be investigated in more detail, also considering possible corrosion mechanisms of domestic stoves.

Despite the presence of high levels of heavy metals, which may pose some-concerns for the re-use of ash from wood pellet combustion, XRD patterns highlight the presence of some potentially useful phases such as $\mathrm{CaO}$ and $\mathrm{MgO}$, that may be recovered for re-use in certain applications. This is very interesting and is a challenging research topic, and it correlates well with the European "raw material" initiative. $\mathrm{CaO}$ and $\mathrm{MgO}$ can be found in high quantities in biomass ashes: up to $63 \%$ for $\mathrm{CaO}$ and $12 \%$ for $\mathrm{MgO}$ (Vassilev et al., 2013b). Furthermore, carbonates can be formed by reaction of these phases with water and carbon dioxide. Since there are high levels of heterogeneity in wood pellet materials, whose physical and chemical properties depend on several factors such as the part that is used (e.g. bark, wood or branches) and typology (e.g. forest or herbaceous). The resulting ash composition will not only relate to the origin and composition of the waste pellets, but also to the stoves in which the pellets are burned. One aim of this paper is in this work has been to show that wery-different ashes, produced from pellets with different compositions and burned in different stoves, can be utilized in the context of compensating raw materials scarcity. Indeed, despite their differences in composition, all ashes contain useful phases that can potentially be employed to produce new materials and products. Suggested future work may therefore consider the effects of different combustion systems.

In this work, wood pellet ashes were employed as a stabilizing agent, with the addition of RHA and coal fly ash, to treat MSWI fly ash. We have recently shown (Bosio et al., 2014) that the stabilization of heavy metals can be obtained by a sustainable process, based on the use of all wastes and by products since the employment of amorphous silica and calcium oxide (or hydroxide) sources allows the occurrence of two reactions, silica stabilization and carbonation. RHA contains amorphous silica that can be used in chemical stabilization of $\mathrm{Pb}$ and $\mathrm{Zn}$ (Bosio et al., 2014). X-ray absorption spectroscopy identified $\mathrm{Pb}$ and $\mathrm{Zn}$ silicates $\left(\mathrm{PbSiO}_{3}\right.$ and $\left.\mathrm{Zn}_{2} \mathrm{SiO}_{4}\right)$ as main phases obtained after stabilization of MSWI fly ash with colloidal silica (Struis et al., 2013). Moreover, the evidence of carbonation supports the hypothesis of formation of immobile metal carbonates as an additional mechanism of metal entrapment.

Data reported in Table 3, show that the leachability of $\mathrm{Pb}$ and $\mathrm{Zn}$ is highly decreased in the stabilized samples. This is evident considering the first leaching test, made one month after the stabilization procedure (week 5). This is verified for both the reference sample and all samples prepared using all the wood pellet ashes 
employed. The leaching experiments made during weeks 6, 7 and 8 show that all samples remain stable during this time period. In addition, as already found (Bosio et al., 2014), the concentration of $\mathrm{Pb}$ and $\mathrm{Zn}$ in the leaching solutions decreased with time, in respect to the data obtained after week 5 supporting further stabilization with time. Stabilization of residual $\mathrm{Pb}$ and $\mathrm{Zn}$ with time is a consequence of carbonation (Rodella et al., 2016). In particular, $\mathrm{Pb}$ concentrations were often lower than the detection limit. To better highlight the change of $\mathrm{Pb}$ and $\mathrm{Zn}$ concentrations during the time, these values (reported in Table 3) are displayed in Fig. 3. This result supports the conclusion that wood pellet ash, independently from the origin and the burning system, represents an effective substitute for FGD residue, to promote heavy metals stabilization. Additionally, the use of this ash allows a valuable material to be obtained by employing all waste starting materials, that can have application as a filler for example in polymer composites (Benassi et al., 2015).

The leaching test results, considered holistically, highlight some final considerations. Sulfur is highly leachable in the reference sample prepared using the FGD residue in the stabilization process whereas for the CR samples it is always very low (often near to the detection limit). Samples A and C show, 8 weeks after the stabilization process, leachate concentrations of sulfur higher than $10 \mathrm{mg} / \mathrm{L}$. This is probably due to the formation of some soluble phases containing sulfur (in accord with XRD data, see Table 4).

XRD patterns collected on all stabilized samples after 10 weeks (with the exception of the reference sample (see Fig. 4) show the presence of the same phases. The biggest difference in the reference sample is the soluble salt $\mathrm{KCl}$, in accordance with the data obtained from the leaching tests (see Table 3). Another difference from the standard sample is the absence of gypsum in the stabilized samples made using wood pellet ashes. Indeed, the FGD residues have a high content of S (Struis et al., 2013). After the stabilization process it is notable that the reference sample shows in addition to the presence of gypsum, other calcium sulfate phases (anhydrite $\left(\mathrm{CaSO}_{4}\right)$ and hannebachite $\left(\mathrm{Ca}(\mathrm{SO})_{3} \cdot 0.5\left(\mathrm{H}_{2} \mathrm{O}\right)\right.$ ) (see Table 4). This generally does not occur for the other CR samples. Only several weeks after stabilization some sulfate phases appear (generally gypsum, see Table 4) for samples stabilized with wood biomass ash. It is clear that the employment of this ash, instead of FGD residues, can provide several advantages in view of the possible reuse of this material in building applications, due to the absence of sulfate phases in the first weeks after the stabilization.

XRD patterns collected three months after the stabilization process show the presence of vaterite $\left(\mu-\mathrm{CaCO}_{3}\right)$ for all samples realized with the wood pellet ashes (see Table 4).

Thaumasite $\left(\mathrm{Ca}_{3}\left(\mathrm{SO}_{4}\right)\left[\mathrm{Si}(\mathrm{OH})_{6}\right]\left(\mathrm{CO}_{3}\right) \cdot 12\left(\mathrm{H}_{2} \mathrm{O}\right)\right)$ has disappeared and, generally, gypsum can be found in the patterns. Thaumasite phase is generally formed at low temperatures (below $15^{\circ} \mathrm{C}$ ), with an abundance of moisture and the availability of calcium silicate, sulfate and carbonate ions (Bensted, 1999). However, thaumasite formation has been reported in cementitious systems at higher temperatures (Bassuoni and Nehdi, 2009). Thaumasite was demonstrated to be formed with $\mathrm{pH}>10.5$ (Gaze and Crammond, 2000) and decomposes with $\mathrm{pH}<10.5$ to form calcite in the deteriorated matrix (Rahman and Bassuoni, 2014). When sulfate is present and the $\mathrm{pH}$ is lower than 10.5 gypsum can be formed (Rahman and Bassuoni, 2014). These findings are in accordance with the results shown in a recent publication (Bosio et al., 2014) were XRD patterns of all stabilized samples collected three months after the stabilization showed an increase in calcite contribution. This is attributed to a slow rate of carbonation in the stabilized samples. The MSWI fly ash had pH 12.5 and this value remained unaltered for all samples in the first weeks. Because of the carbonation, the $\mathrm{pH}$ of all stabilized 
samples (three months after the stabilization) was observed to be in the $\mathrm{pH}$ range ef $\mathrm{pH} 7.5-8.5$. This is consistent with the disappearance of thaumasite.

Concerning vaterite, this phase is the thermodynamically least stable phase among three polymorphic forms of calcium carbonate, but it is frequently formed under specific conditions. It was previously found in carbonation experiments involving MWSI fly ash (Bosio et al., 2014). Furthermore, it has been shown that the direct aqueous carbonation of FGD residue produces a mixture of vaterite and calcite phases (Song et al., 2012). As a consequence, due to the carbonation reaction occurring for all samples, the final phases present in aged samples are calcite, gypsum, vaterite, and some crystalline silica and soluble salts. The increase of calcite contribution allows us to conclude that carbon dioxide sequestration is occurring and can thus be considered as an additional advantage of the proposed technology. It shows that biomass combustion can not only be considered to not contribute to the greenhouse effect, but also, for the first time, it has been shown to be a potential means to promote the $\mathrm{CO}_{2}$ sequestration.

To evaluate the amount of carbon dioxide that can be sequestered when using wood pellet biomass ashes instead of FGD residues, TGA and TG-MS measurements were performed (see Table 5 and Fig. 5). According to literature, three modes of decomposition of calcium carbonate can be distinguished (Thiery et al., 2007) and progressively appear when the level of carbonation increases: first, mode $\mathrm{I}\left(780^{\circ} \mathrm{C}<\mathrm{T}<990^{\circ} \mathrm{C}\right)$, then, mode II $\left(680^{\circ} \mathrm{C}<\mathrm{T}<780^{\circ} \mathrm{C}\right)$, and finally, mode III $\left(550^{\circ} \mathrm{C}<\mathrm{T}<680^{\circ} \mathrm{C}\right)$. Mode I is attributed to the decomposition of highly crystalline $\mathrm{CaCO}_{3}$, namely calcite. Mode II decomposition is attributed to less perfect crystalline calcium carbonate, as for example vaterite (Šauman, 1971). Finally, mode III decomposition is attributed to the presence of amorphous calcium carbonate (Thiery et al., 2007). These three decomposition modes appear in the TGA and TG-MS data for all CR samples. TGA analyses (Table 5) show significant mass loss over the aforementioned temperature range indicated by Thiery et al. (2007). Moreover, mass spectrometry data referring to MW $=44$ $\left(\mathrm{CO}_{2}\right)$ shows a trend that is consistent with the TGA behavior in these temperature ranges. As a consequence, from the data obtained from TGA and TG-MS, and summarized in Table 5, it is clearly shown that the amount of released $\mathrm{CO}_{2}$ is extremely significant for all samples. The total weight loss of all $\mathrm{CR}$ samples attributed to $\mathrm{CO}_{2}$ release is in the range of $19-25 \%$ for all samples, corresponding to a total calcium carbonate content ranging from 36 to $48 \%$.

Although it is not the most prominent phase, calcium carbonate in the form of calcite was also found in the wood pellet wood-ash (see Fig. 2). In particular, in the XRD patterns shown in Fig. 2 it is possible to identify several phases containing $\mathrm{Ca}$ in these samples. Moreover, it is also evident that wood pellet ash contains several other crystalline phases. In addition, an amorphous phase is also present. As a consequence, TGA diagrams of these samples (not shown) are very complicated and the quantification of the original, pre-existing calcite is extremely difficult. However, from the data reported in Table 2, it is possible to conservatively estimate the theoretical total amount of calcite originally present in the wood ash samples, that would be added to the CR samples, by attributing all the Ca present in the wood pellet ash, to calcite. On this basis, i.e. supposing that all $\mathrm{Ca}$ in wood pellet ash is contained in the calcite (this allows to make a very conservative estimation), the theoretical maximum amount of calcite added to CR samples, by using wood pellet ash, is less than $6 \%$.

The obtained values for the reference sample are consistent with previous analysis realized by means of $\mathrm{XRD}$, that allowed quantification of the amounts of only calcite and vaterite (crystallized phases), which were found to be greater than 20\% (in the present case it results in about 22\%) (Bontempi et al., 2010b). In particular, 
the contributions due to amorphous calcium carbonate and vaterite (very low) of all samples obtained here by means of wood pellet ash stabilization are comparable with values obtained for the reference CR sample. The main difference with the reference sample can be attributed to the first mode of calcium carbonate decomposition (calcite), with higher results for samples realized with wood pellet ashes in respect to the reference sample. From the data obtained by means of TGA it can be shown that mode III decomposition corresponds to approximately one half of the weight loss. This indicates that a substantial amount of amorphous calcium carbonate is present in the samples.

It is important to highlight that in the range of $780-990^{\circ} \mathrm{C}, \mathrm{SO}_{2}$ decomposition also takes place (see Fig. 5 (b)). However, this contribution is undetectable for samples realized using wood pellet ashes. On the contrary, this contribution is appreciable in the reference sample. This means that the values of mass loss attributed to calcium carbonate decomposition are lower for the $\mathrm{CR}$ reference sample (in respect to the values reported in Table 5). As a consequence, the carbonation capability of other COSMOS-RICE samples obtained using wood pellet ash, are much higher than that of the reference CR sample.

\section{Conclusions}

In the coming years waste management strategy must address improved sustainability by closing production cycles, wherein a waste material will become the raw material input for production in another plant or process, improving both environmental and economic benefits through efficient reuse of resources. Moreover, the technologies used for the valorization of wastes must, as much as possible, mitigate any additions to the environmental footprint to the existing waste-derived processes. The work presented here shows that wood biomass ash, which can represent an unexpected environmental problem, can be reused, with the addition of industrial ashes, to stabilize MSWI fly ash and to produce a new material that could be employed to partially solve the European problem of "raw materials". In particular, our results demonstrate that ash produced by domestic and industrial combustion can potentially be recovered, to provide decreased waste generation from these sectors and to improve the sustainability of some industrial processes (as for example thermal valorization of waste and the coal combustion), by producing added value compounds. The final obtained product has been shown to provide carbon dioxide permanent sequestration, with a carbonate content higher in samples realized by using wood pellet ash, in respect to sample realized by using FGD residues. In particular, TGA analysis showed that the TGA-mass spectroscopy determined weight loss of CR samples attributed to the carbonates decomposition is always higher than $20 \%$ for samples realized using wood pellet ash, making it possible to conclude that for this process wood pellet biomass $\mathrm{CO}_{2}$ conversion can be negative.

\section{References}

Ahmaruzzaman M (2010) A review on the utilization of fly ash. Prog Energ Combust 36(3): 327-363. doi:10.1016/j.pecs.2009.11.003

Arranz JI, Miranda MT, Montero I, Sepúlveda FJ, Rojas CV (2015) Characterization and combustion behavior of commercial and experimental wood pellets in South West Europe. Fuel 142: 199-207. doi:10.1016/j.fuel.2014.10.059

Bankiewicz D, Yrjas P, Hupa M (2009) High-Temperature Corrosion of Superheater Tube Materials Exposed to Zinc Salts†. Energ Fuel 23: 3469-3474. DOI: 10.1021/ef801012z 
Bassuoni MT, Nehdi ML (2009) Durability of self-consolidating concrete to different exposure regimes of sodium sulfate attack. Mater Struct 42(8): 1039-1057. DOI: 10.1617/s11527-008-9442-2

Benassi L, Franchi F, Catina D, Cioffi F, Rodella N, Borgese L, Pasquali M, Depero LE, Bontempi E (2015) Rice Husk Ash to Stabilize Heavy Metals Contained in Municipal Solid Waste Incineration Fly Ash: First Results by Applying New Pre-treatment Technology. Materials 8(10): 6868-6879. doi:10.3390/ma8105346

Bensted J (1999) Thaumasite — background and nature in deterioration of cements, mortars and concretes. Cement Concrete Comp 21(2): 117-121. doi:10.1016/S0958-9465(97)00076-0

Besco S, Bosio A, Brisotto M, Depero LE, Lorenzetti A, Bontempi E, Bonora R, Modesti M (2014) Structural and Mechanical Characterization of Sustainable Composites Based on Recycled and Stabilized Fly Ash. Materials 7(8): 5920-5933. doi:10.3390/ma7085920

Besco S, Brisotto M, Gianoncelli A, Depero LE, Bontempi E, Lorenzetti A, Modesti M (2013) Processing and properties of polypropylene-based composites containing inertized fly ash from municipal solid waste incineration. J Appl Polym Sci: 4157-4164. doi:10.1002/app.39692

Bontempi E, Zacco A, Borgese L, Gianoncelli A, Ardesi R, Depero LE (2010a) A new method for municipal solid waste incinerator (MSWI) fly ash inertization, based on colloidal silica. J Environ Monitor 12(11): 2093-2099. DOI: 10.1039/c0em00168f

Bontempi E, Zacco A, Borgese L, Gianoncelli A, Ardesi R, Depero LE (2010b) A New Powder Filler, Obtained by Applying a New Technology for Fly Ash Inertisation Procedure. Adv Sci Tech 62: 27-33. DOI: 10.4028/www.scientific.net/AST.62.27

Bontempi E, Bosio A, Depero LE, Gianoncelli A (2012) patent MI2012A001382

Borgese L, Zacco A, Bontempi E, Colombi P, Bertuzzi R, Ferretti E, Tenini S, Depero LE (2009) Total reflection of $\mathrm{x}$-ray fluorescence (TXRF): a mature technique for environmental chemical nanoscale metrology. Meas Sci Technol 20(8): 1-7. http://dx.doi.org/10.1088/0957-0233/20/8/084027

Bosio A, Rodella N, Gianoncelli A, Zacco A, Borgese L, Depero LE, Bingham PA, Bontempi E (2013) A new method to inertize incinerator toxic fly ash with silica from rice husk ash. Environ Chem Lett 11(4): 329333. doi:10.1007/s10311-013-0411-9

Bosio A, Zacco A, Borgese L, Rodella N, Colombi P, Benassi L, Depero LE, Bontempi E (2014) A sustainable technology for $\mathrm{Pb}$ and $\mathrm{Zn}$ stabilization based on the use of only waste materials: A green chemistry approach to avoid chemicals and promote $\mathrm{CO}_{2}$ sequestration. Chem Eng J 253: 377-384. doi:10.1016/j.cej.2014.04.080

CEN EN 12457-2 normative. European Committee for Standardization, Brussels, Belgium, 2002

Chandrasekaran SR, Hopke PK, Rector L, Allen G, Lin L (2012) Chemical Composition of Wood Chips and Wood Pellets. Energ Fuel 26(8): 4932-4937. DOI: 10.1021/ef300884k

Colangelo F, Cioffi R, Montagnaro F, Santoro L (2012) Soluble salt removal from MSWI fly ash and its stabilization for safer disposal and recovery as road basement material, Waste Manage 32(6): 1179-1185. DOI: 10.1016/j.wasman.2011.12.013

Commission, E., The European Innovation Partnership (EIP) on Raw Materials. https://ec.europa.eu/growth/tools-databases/eip-raw-materials/en/content/european-innovation-partnershipeip-raw-materials. Accessed 26 July 2016.

COSMOS-RICE, PROJECT (http://www.cosmos-rice.csmt.eu/). Accessed 26 July 2016. 
De A, Awasthi A, Tiwari MK (2015) Robust formulation for optimizing sustainable ship routing and scheduling problem. Characterisation of waste - Leaching - Compliance test for leaching of granular waste materials and sludges - Part 2: One stage batch test at a liquid to solid ratio of $10 \mathrm{l} / \mathrm{kg}$ for materials with particle size below $4 \mathrm{~mm}$ (without or with size reduction). IFAC-PapersOnLine 48(3): 368-373. Europe, 2002.

EUROSTAT, 2013 (http://ec.europa.eu/eurostat). Accessed 26 July 2016.

Funari V, Braga R, Bokhari SNH, Dinelli E, Meisel T (2015) Solid residues from Italian municipal solid waste incinerators: A source for "critical" raw materials. Waste Manage 45, 206-216. DOI: 10.1016/j.wasman.2014.11.005

Gaze ME, Crammond NJ (2000) The formation of thaumasite in a cement: lime: sand mortar exposed to cold magnesium and potassium sulfate solutions. Cement Concrete Comp 22(3): 209-222. doi:10.1016/S09589465(00)00002-0

Guarienti M, Gianoncelli A, Bontempi E, Moscoso Cardozo S, Borgese L, Zilioli D, Mitola S, Depero LE, Presta M (2014) Biosafe inertization of municipal solid waste incinerator residues by COSMOS technology. J Hazard Mater 279: 311-321. DOI:10.1016/j.jhazmat.2014.07.017

Katers JF, Snippen AJ, Puettmann ME (2012) Life-Cycle Inventory of Wood Pellet Manufacturing and Utilization in Wisconsin*. Forest Prod J 62(4): $289-295$

Hansson J, Hackl R (2016) The potential influence of sustainability criteria on the European Union pellets market-the example of Sweden. WIREs Energy Environ 5(4): 413-429.

Loo Sv, Koppejan J, Bioenergy, I.E.A., Co-Firing., T.B.C.a. (2002) Handbook of biomass combustion and Cofiring

Mehta A, Siddique R (2016) An overview of geopolymers derived from industrial by-products. Constr Build Mater 127: 183-198.

Mellbo P, Sarenbo S, Stålnacke O, Claesson T (2008) Leaching of wood ash products aimed for spreading in forest floors--influence of method and L/S ratio. Waste manage 28(11): 2235-2244. doi:10.1016/j.wasman.2007.09.037

Niu Y, Tan H, Hui S (2016) Ash-related issues during biomass combustion: Alkali-induced slagging, silicate melt-induced slagging (ash fusion), agglomeration, corrosion, ash utilization, and related countermeasures. Prog Energ Combust 52: 1-61. doi:10.1016/j.pecs.2015.09.003

Orecchio S, Amorello D, Barreca S, Valenti A (2016) Wood pellets for home heating can be considered environmentally friendly fuels? Polycyclic aromatic hydrocarbons (PAHs) in their ashes. Microchem J 124: 267-271. doi:10.1016/j.microc.2015.09.003

Ponsot I, Bernardo E, Bontempi E, Depero LE, Detsch R, Chinnam RK, Boccaccini AR (2015) Recycling of pre-stabilized municipal waste incinerator fly ash and soda-lime glass into sintered glass-ceramics. J Clean Prod 89: 224-230. doi:10.1016/j.jclepro.2014.10.091

Priyanto DE, Ueno S, Sato N, Kasai H, Tanoue T, Fukushima H (2016) Ash transformation by co-firing of coal with high ratios of woody biomass and effect on slagging propensity. Fuel 174: 172-179. doi:10.1016/j.fuel.2016.01.072

Rahman MM, Bassuoni MT (2014) Thaumasite sulfate attack on concrete: Mechanisms, influential factors and mitigation. Constr Build Mater 73: 652-662. doi:10.1016/j.conbuildmat.2014.09.034 
Ridha FN, Wu Y, Manovic V, Macchi A, Anthony EJ (2015) Enhanced $\mathrm{CO}_{z}$-capture by biomass templated $\mathrm{Ca}(\mathrm{OH})_{2}$-based pellets. Chem Eng J 274: 69-75. doi:10.1016/j.cej.2015.03.041

Rodella N, Bosio A, Dalipi R, Zacco A, Borgese L, Depero LE, Bontempi E (2014) Waste silica sources as heavy metal stabilizers for municipal solid waste incineration fly ash. Arabian $\mathrm{J}$ Chem, in press. doi:10.1016/j.arabjc.2014.04.006

Rodella N, Pasquali M, Zacco A, Bilo F, Borgese L, Bontempi N, Tomasoni G, Depero LE, Bontempi E (2016) Beyond waste: new sustainable fillers from fly ashes stabilization, obtained by low cost raw materials. Heliyon 2(9): e00163.

Šauman Z (1971) Carbonization of porous concrete and its main binding components. Cem Concr Res 1(6): 645-662. doi:10.1016/0008-8846(71)90019-6

Siefert NS, Litster S (2013) Exergy and economic analyses of advanced IGCC-CCS and IGFC-CCS power plants. Appl Energy 107: 315-328. doi:10.1016/j.apenergy.2013.02.006

Sjølie HK, Solberg B (2011) Greenhouse gas emission impacts of use of Norwegian wod pellets: a sensitivity analysis. Enviren Sei Policy 14(8): 1028 1040. doi:10.1016/j.envsei.2011.07.011

Song K, Jang YN, Kim W, Lee MG, Shin D, Bang JH, Jeon CW, Chae SC (2012) Precipitation of calcium carbonate during direct aqueous carbonation of flue gas desulfurization gypsum. Chem Eng J 213: 251-258. doi:10.1016/j.cej.2012.10.010

Steenari BM, Karlssen LG, Lindqvist O (1999) Evaluation of the leaching characteristics of wood ash and the influence of ash agglomeration. Biomass Bioenergy 16(2): 119-136. doi:10.1016/S0961-9534(98)00070-1

Struis RPWJ, Pasquali M, Borgese L, Gianoncelli A, Gelfi M, Colombi P, Thiaudiere D, Depero LE, Rizzo G, Bontempi E (2013) Inertisation of heavy metals in municipal solid waste incineration fly ash by means of colloidal silica - a synchrotron X-ray diffraction and absorption study. RSC Adv 3(34): 14339-14351. DOI: $10.1039 / C 3 R A 41792 A$

Thiery M, Villain G, Dangla P, Platret G (2007) Investigation of the carbonation front shape on cementitious materials: Effects of the chemical kinetics. Cem Concr Res 37(7): 1047-1058. doi:10.1016/j.cemconres.2007.04.002

Valverde JM, Sanchez-Jimenez PE, Perez-Maqueda LA (2015) Ca-looping for postcombustion $\mathrm{CO}_{2}$ capture: A comparative analysis on the performances of dolomite and limestone. Appl Energy 138: 202-215. doi: 10.1016/j.apenergy.2014.10.087

Van den Heede P, Ringeot N, Beirnaert A, Van Brecht A, Van den Brande E, De Shutter G, De Belie N (2016) Sustainable High Quality Recycling of Aggregates from Waste to Energy, Treated in a Wet Bottom Ash Processing Installation, for Use in Concrete Products. Materials 9(1), Article 9: 124. doi:10.3390/ma9010009

Vassilev SV, Baxter D, Andersen LK, Vassileva CG (2013a) An overview of the composition and application of biomass ash. Fuel 105: 19-39. doi:10.1016/j.fuel.2012.09.041

Vassilev SV, Baxter D, Vassileva CG (2013b) An overview of the behaviour of biomass during combustion: Part I. Phase-mineral transformations of organic and inorganic matter. Fuel 112: 391-449. doi:10.1016/j.fuel.2013.05.043

Xin-gang Z, Gui-wu J, Ang L, Yun L (2016) Technology, cost, a performance of waste-to-energy incineration industry in China. Renewable Sustainable Energy Rev 55: 115-130. doi:10.1016/j.rser.2015.10.137 
Yang J, Wang Q, Luo Q, Wang Q, Wu T (2009) Biosorption behavior of heavy metals in bioleaching process of MSWI fly ash by Aspergillus niger. Biochem Eng J 46(3): 294-299. doi:10.1016/j.bej.2009.05.022

Ye N, Chen Y, Yang J, Liang S, Hu Y, Xiao B, Huang Q, Shi Y, Hu J, Wu X (2016) Co-disposal of MSWI fly ash and Bayer red mud using an one-part geopolymeric system. J Hazard Mater 318: 70-78. DOI: 10.1016/j.jhazmat.2016.06.042

Zacco A, Borgese L, Gianoncelli A, Struis RWJ, Depero LE, Bontempi E (2014) Review of fly ash inertisation treatments and recycling. Environ Chem Lett 12(1): 153-175. DOI: 10.1007/s10311-014-0454-6

Zaceo A, Gianoncelli A, Ardesi R, Sacrato S, Guerini L, Bontempi E, Tomasoni G, Alberti M, Depero LE (2012) Use of colloidal silica to obtain a new inert from municipal solid waste incinerator (MSWI) fly ash: first results about reuse. Clean Technol Environ Policy 14(2): 291-297. doi:10.1007/s10098-011-0401-1

Zaetang Y, Wongsa A, Sata V, Chindaprasirt P (2015) Use of coal ash as geopolymer binder and coarse aggregate in pervious concrete. Constr Build Mater 96: 289 295. doi:10.1016/j.conbuildmat.2015.08.076 


\section{Table 1}

Analyzed composition (mg/kg) of wood pellet samples (A, B, C, D, and E) and limits of detection (LOD) of determined elements.

\begin{tabular}{|c|c|c|c|c|c|c|c|c|c|c|c|}
\hline \multirow[b]{2}{*}{ Element } & \multicolumn{2}{|c|}{$\mathbf{A}$} & \multicolumn{2}{|c|}{ B } & \multicolumn{2}{|c|}{ C } & \multicolumn{2}{|c|}{ D } & \multicolumn{2}{|c|}{$\mathbf{E}$} & \multirow{2}{*}{$\begin{array}{c}\text { LOD } \\
(\mathrm{mg} / \mathrm{kg})\end{array}$} \\
\hline & Mean & SD & Mean & SD & Mean & $\mathrm{SD}$ & Mean & SD & Mean & SD & \\
\hline $\mathrm{P}$ & - & - & - & - & 130 & 10 & 80 & 10 & 140 & 40 & 110 \\
\hline$S$ & 270 & 30 & 280 & 30 & 1700 & 500 & 630 & 60 & 1200 & 200 & 70 \\
\hline $\mathrm{Cl}$ & 760 & 80 & 540 & 50 & 1300 & 100 & 430 & 40 & 1300 & 300 & 40 \\
\hline $\mathrm{K}$ & 170 & 20 & 270 & 30 & 330 & 30 & 200 & 20 & 340 & 50 & 25 \\
\hline $\mathrm{Ca}$ & 540 & 50 & 820 & 80 & 880 & 90 & 820 & 80 & 1100 & 100 & 20 \\
\hline $\mathrm{Ti}$ & - & - & 15 & 2 & - & - & - & - & - & - & 4 \\
\hline $\mathrm{Cr}$ & 3 & 1 & 3.5 & 0.5 & - & - & - & - & - & - & 2 \\
\hline $\mathrm{Mn}$ & 35 & 3 & 24 & 2 & 36 & 3 & 48 & 5 & 38 & 4 & 5 \\
\hline $\mathrm{Fe}$ & 260 & 30 & 350 & 30 & 340 & 30 & 370 & 40 & 390 & 40 & 5 \\
\hline $\mathrm{Ni}$ & 31 & 3 & 5.0 & 0.5 & 5 & 0.6 & 6 & 1 & 10 & 1 & 3 \\
\hline $\mathrm{Cu}$ & 5.8 & 0.6 & - & - & 4 & 1 & - & - & - & - & 2 \\
\hline $\mathrm{Zn}$ & 7 & 1 & 17 & 2 & 10 & 1 & 12 & 3 & 54 & 5 & 2 \\
\hline As & 14 & 1 & - & - & 29 & 3 & 16 & 1 & 25 & 4 & 2 \\
\hline $\mathrm{Br}$ & - & - & - & - & - & - & - & - & - & - & 1 \\
\hline $\mathrm{Rb}$ & - & - & - & - & - & - & - & - & - & - & 6 \\
\hline $\mathrm{Sr}$ & - & - & - & - & - & - & - & - & - & - & 10 \\
\hline $\mathrm{Ba}$ & - & - & - & - & - & - & - & - & - & - & 75 \\
\hline $\mathrm{Pb}$ & - & - & - & - & - & - & - & - & - & - & 6 \\
\hline
\end{tabular}

Note: $S D$ is the standard deviation of three replicates 
Table 2

Analyzed composition (mg/kg) of wood pellet ashes (A, B, C, D and E), after combustion in domestic stoves.

\begin{tabular}{|c|c|c|c|c|c|c|c|c|c|c|}
\hline \multirow[b]{2}{*}{ Element } & \multicolumn{2}{|c|}{ A } & \multicolumn{2}{|c|}{ B } & \multicolumn{2}{|c|}{$\mathbf{C}$} & \multicolumn{2}{|c|}{ D } & \multicolumn{2}{|c|}{$\mathbf{E}$} \\
\hline & Mean & SD & Mean & SD & Mean & SD & Mean & SD & Mean & SD \\
\hline $\mathrm{P}$ & 4900 & 500 & 6500 & 600 & 4000 & 400 & 5500 & 500 & 6700 & 700 \\
\hline S & 2800 & 300 & 4300 & 600 & 5000 & 500 & 2900 & 300 & 3400 & 300 \\
\hline $\mathrm{Cl}$ & 650 & 70 & 400 & 100 & 510 & 60 & 900 & 100 & 1100 & 100 \\
\hline $\mathrm{K}$ & 45000 & 5000 & 57000 & 6000 & 55000 & 5000 & 46000 & 5000 & 57000 & 6000 \\
\hline $\mathrm{Ca}$ & 81000 & 8000 & 110000 & 10000 & 71000 & 7000 & 150000 & 20000 & 110000 & 10000 \\
\hline $\mathrm{Ti}$ & 900 & 100 & 570 & 60 & 4000 & 400 & 1000 & 100 & 300 & 30 \\
\hline $\mathrm{Cr}$ & 100 & 10 & 200 & 20 & 60 & 6 & 100 & 10 & 40 & 4 \\
\hline $\mathrm{Mn}$ & 13000 & 1000 & 43800 & 400 & 7700 & 700 & 12000 & 1000 & 10000 & 1000 \\
\hline $\mathrm{Fe}$ & 10000 & 1000 & 9600 & 100 & 10000 & 1000 & 12000 & 1000 & 4800 & 500 \\
\hline $\mathrm{Ni}$ & 37 & 4 & - & - & 42 & 4 & 35 & 3 & 27 & 3 \\
\hline $\mathrm{Cu}$ & 160 & 20 & 180 & 20 & 350 & 30 & 150 & 20 & 130 & 10 \\
\hline $\mathrm{Zn}$ & 570 & 60 & 790 & 80 & 1300 & 100 & 550 & 50 & 1000 & 100 \\
\hline As & 40 & 4 & 50 & 5 & 42 & 4 & 40 & 4 & 46 & 5 \\
\hline $\mathrm{Br}$ & 72 & 10 & 12 & 2 & - & - & - & - & - & - \\
\hline $\mathrm{Rb}$ & 140 & 10 & 300 & 30 & 160 & 20 & 130 & 10 & 200 & 20 \\
\hline $\mathrm{Sr}$ & 460 & 50 & 600 & 100 & 440 & 40 & 650 & 60 & 350 & 30 \\
\hline $\mathrm{Ba}$ & 710 & 70 & 1000 & 100 & - & - & 1200 & 100 & 1100 & 100 \\
\hline $\mathrm{Pb}$ & 15 & 1 & 8 & 1 & 22 & 2 & 15 & 1 & 14 & 2 \\
\hline
\end{tabular}

Note: $S D$ is the standard deviation of three replicates 
Table 3

Results of leaching tests made on MSWI fly ash and samples treated with the COSMOS-RICE procedure. A reference sample was also realized, following the standard procedure (Bosio et al., 2014), i.e. employing the FGD residues instead of wood pellet ash.

\begin{tabular}{|c|c|c|c|c|c|c|c|c|c|c|c|c|c|c|}
\hline \multirow{2}{*}{$\begin{array}{c}\text { Elemen } \\
\mathrm{t}\end{array}$} & \multirow{2}{*}{$\begin{array}{c}\text { Statistic } \\
\mathrm{s}\end{array}$} & \multirow{2}{*}{$\begin{array}{l}\text { MSWI } \\
\text { fly ash } \\
(\mathrm{mg} / \mathrm{L} \\
\text { ) }\end{array}$} & \multicolumn{4}{|c|}{$\begin{array}{l}\text { Reference sample } \\
\qquad(\mathrm{mg} / \mathrm{L})\end{array}$} & \multicolumn{4}{|c|}{$\begin{array}{c}\text { CR sample A } \\
(\mathrm{mg} / \mathrm{L})\end{array}$} & \multicolumn{4}{|c|}{$\begin{array}{c}\text { CR sample B } \\
(\mathrm{mg} / \mathrm{L})\end{array}$} \\
\hline & & & $\begin{array}{l}\text { Wee } \\
\text { k } 5\end{array}$ & $\begin{array}{l}\text { Wee } \\
\text { k } 6\end{array}$ & $\begin{array}{l}\text { Wee } \\
\text { k } 7\end{array}$ & $\begin{array}{l}\text { Wee } \\
\mathrm{k} 8\end{array}$ & $\begin{array}{l}\text { Wee } \\
\text { k } 5\end{array}$ & $\begin{array}{l}\text { Wee } \\
\text { k } 6\end{array}$ & $\begin{array}{l}\text { Wee } \\
\text { k } 7\end{array}$ & $\begin{array}{l}\text { Wee } \\
\mathrm{k} 8\end{array}$ & $\begin{array}{l}\text { Wee } \\
\text { k } 5\end{array}$ & $\begin{array}{l}\text { Wee } \\
\text { k } 6\end{array}$ & $\begin{array}{l}\text { Wee } \\
\text { k } 7\end{array}$ & $\begin{array}{l}\text { Wee } \\
\text { k } 8\end{array}$ \\
\hline \multirow{2}{*}{$S$} & Mean & - & 190 & 130 & 90 & 170 & 9 & - & - & 12 & - & - & - & - \\
\hline & SD & & 20 & 20 & 5 & 20 & 5 & & & 2 & & & & \\
\hline \multirow{2}{*}{$\mathrm{Cl}$} & Mean & 6700 & 1400 & 2600 & 3800 & 1300 & 3300 & 2800 & 3300 & 3800 & 3800 & 2700 & 3300 & 2800 \\
\hline & SD & 100 & 100 & 100 & 500 & 200 & 400 & 300 & 300 & 400 & 400 & 400 & 300 & 300 \\
\hline \multirow{2}{*}{$\mathrm{K}$} & Mean & 1170 & 180 & 450 & 600 & 200 & 1000 & 800 & 1000 & 1000 & 1200 & 900 & 1100 & 900 \\
\hline & SD & 40 & 20 & 40 & 100 & 30 & 100 & 100 & 100 & 100 & 100 & 200 & 100 & 100 \\
\hline \multirow{2}{*}{$\mathrm{Ca}$} & Mean & 5050 & 1400 & 2100 & 3300 & 1200 & 1700 & 1500 & 1700 & 1700 & 2100 & 1500 & 1700 & 1000 \\
\hline & SD & 40 & 100 & 200 & 400 & 100 & 200 & 100 & 200 & 200 & 200 & 200 & 200 & 100 \\
\hline \multirow[b]{2}{*}{$\mathrm{Fe}$} & Mean & - & 0.3 & - & - & 0.20 & - & - & - & - & - & - & - & - \\
\hline & SD & & 0.1 & & & 0.04 & & & & & & & & \\
\hline \multirow[t]{2}{*}{$\mathrm{Zn}$} & Mean & 9 & 0.38 & 0.32 & 0.51 & 0.19 & 0.44 & 0.22 & 0.01 & 0.35 & 0.67 & 0.25 & 0.12 & 0.24 \\
\hline & SD & 1 & 0.04 & 0.07 & 0.05 & 0.02 & 0.05 & 0.02 & 0.01 & 0.04 & 0.19 & 0.03 & 0.02 & 0.02 \\
\hline \multirow{2}{*}{ As } & Mean & - & - & - & - & - & - & 0.13 & - & - & 0.11 & 0.12 & 0.10 & 0.10 \\
\hline & SD & & & & & & & 0.01 & & & 0.02 & 0.01 & 0.01 & 0.01 \\
\hline \multirow{2}{*}{$\mathrm{Br}$} & Mean & 104 & 40 & 46 & 55 & 34 & 50 & 40 & 40 & 53 & 41 & 30 & 37 & 30 \\
\hline & SD & 1 & 4 & 5 & 5 & 3 & 5 & 4 & 4 & 5 & 4 & 3 & 4 & 3 \\
\hline \multirow{2}{*}{$\mathrm{Sr}$} & Mean & 5.38 & 5.5 & 5.5 & 6.5 & 5.9 & 13 & 11 & 11 & 18 & 15 & 12 & 17 & 13 \\
\hline & SD & 0.03 & 0.5 & 0.5 & 0.6 & 0.6 & 1 & 1 & 1.15 & 2 & 1 & 1 & 2 & 1 \\
\hline \multirow{2}{*}{$\mathrm{Ba}$} & Mean & 9.0 & 0.2 & 0.21 & 1.7 & 0.5 & 1.9 & 2.1 & 2.8 & 2.2 & 7.0 & 4.8 & 5.8 & 5.1 \\
\hline & SD & 0.3 & 0.1 & 0.02 & 0.3 & 0.1 & 0.3 & 0.2 & 0.6 & 0.2 & 0.7 & 0.5 & 0.6 & 0.5 \\
\hline \multirow{3}{*}{$\mathrm{Pb}$} & Mean & 30 & - & 0.10 & 1.2 & - & 0.08 & 0.15 & & & & 0.13 & 0.04 & 0.04 \\
\hline & & & & & & & & & & & & & & \\
\hline & SD & 3 & & 0.01 & 0.1 & & 0.01 & 0.01 & & & & 0.02 & 0.02 & 0.03 \\
\hline
\end{tabular}

Note: $S D$ is the standard deviation of three replicates 
Table 3 (continued)

\begin{tabular}{|c|c|c|c|c|c|c|c|c|c|c|c|c|c|}
\hline \multirow{2}{*}{$\begin{array}{c}\text { Elem } \\
\text { ent }\end{array}$} & \multirow{2}{*}{$\begin{array}{c}\text { Statist } \\
\text { ics }\end{array}$} & \multicolumn{4}{|c|}{ CR sample C (mg/L) } & \multicolumn{4}{|c|}{ CR sample D (mg/L) } & \multicolumn{4}{|c|}{ CR sample E (mg/L) } \\
\hline & & Week & Week & Week & $\begin{array}{c}\text { Week } \\
8\end{array}$ & Week & Week & Week & $\begin{array}{c}\text { Week } \\
8\end{array}$ & Week & Week & Week & $\begin{array}{c}\text { Week } \\
8\end{array}$ \\
\hline \multirow{2}{*}{$S$} & Mean & 27 & 2.8 & 0.5 & 20 & 0.6 & - & - & - & 15 & 3.5 & - & 3.5 \\
\hline & SD & 3 & 0.6 & 0.4 & 5 & 0.5 & & & & 4 & 0.4 & & 0.3 \\
\hline \multirow{2}{*}{$\mathrm{Cl}$} & Mean & 2500 & 2800 & 3500 & 1700 & 3800 & 3100 & 3800 & 2600 & 4000 & 2700 & 3700 & 2900 \\
\hline & SD & 500 & 300 & 700 & 200 & 400 & 300 & 400 & 300 & 500 & 300 & 400 & 300 \\
\hline \multirow{2}{*}{$\mathrm{K}$} & Mean & 600 & 800 & 900 & 390 & 1300 & 1100 & 1400 & 860 & 1200 & 800 & 1100 & 800 \\
\hline & SD & 100 & 100 & 200 & 50 & 100 & 100 & 100 & 90 & 200 & 80 & 100 & 100 \\
\hline \multirow{2}{*}{$\mathrm{Ca}$} & Mean & 1500 & 1600 & 1900 & 890 & 2200 & 1500 & 1900 & 1300 & 2500 & 1600 & 2100 & 1600 \\
\hline & SD & 300 & 40 & 400 & 90 & 200 & 100 & 200 & 100 & 200 & 200 & 200 & 200 \\
\hline \multirow{2}{*}{$\mathrm{Mn}$} & Mean & - & - & - & - & 0.21 & - & 0.24 & - & - & - & - & - \\
\hline & SD & & & & & 0.04 & & 0.06 & & & & & \\
\hline \multirow{2}{*}{$\mathrm{Zn}$} & Mean & 0.8 & 0.04 & 0.30 & 0.20 & 0.33 & 0.03 & 0.05 & 0.20 & 0.35 & 0.03 & 0.12 & 0.18 \\
\hline & SD & 0.4 & 0.01 & 0.03 & 0.04 & 0.03 & 0.01 & 0.01 & 0.02 & 0.04 & 0.00 & 0.02 & 0.02 \\
\hline \multirow{2}{*}{ As } & Mean & - & - & - & - & 0.14 & - & 0.030 & 0.09 & 0.14 & - & 0.08 & 0.09 \\
\hline & SD & & & & & 0.02 & & 0.001 & 0.01 & 0.02 & & 0.01 & 0.01 \\
\hline \multirow{2}{*}{$\mathrm{Br}$} & Mean & 39 & 36 & 47 & 36 & 33 & 35 & 39 & 32 & 54 & 34 & 45 & 41 \\
\hline & SD & 6 & 4 & 6 & 4 & 14 & 3 & 4 & 3 & 7 & 3 & 5 & 4 \\
\hline \multirow{2}{*}{$\mathrm{Sr}$} & Mean & 10 & 9 & 12 & 11 & 19 & 14 & 16 & 15 & 11 & 7.0 & 10 & 10 \\
\hline & SD & 1 & 1 & 1 & 1 & 2 & 1 & 2 & 1 & 1 & 0.7 & 1 & 1 \\
\hline \multirow{2}{*}{$\mathrm{Ba}$} & Mean & 1.0 & 0.7 & 2.3 & 0.8 & 6.1 & 5.8 & 5.6 & 3.7 & 2.0 & 2.1 & 2.6 & 2.0 \\
\hline & SD & 0.1 & 0.1 & 0.5 & 0.1 & 0.6 & 0.6 & 0.6 & 0.4 & 0.2 & 0.2 & 0.2 & 0.2 \\
\hline \multirow{2}{*}{$\mathrm{Pb}$} & Mean & 0.06 & - & - & - & 0.05 & - & - & 0.05 & 0.11 & - & - & - \\
\hline & SD & 0.01 & & & & 0.01 & & & 0.01 & 0.02 & & & \\
\hline
\end{tabular}

Note: $S D$ is the standard deviation of three replicates 
Table 4.

Phase analyses from XRD patterns collected at different times (corresponding to the leaching experiments reported in Table 3). Phase analysis from XRD patterns collected on the week 8 sample is also reported. $\mathrm{SiO}_{2}$ quartz and cristobalite, $\mathrm{CaCO}_{3}$ calcite, $\mu-\mathrm{CaCO}_{3}$ vaterite, $\mathrm{Ca}_{3}\left(\mathrm{SO}_{4}\right)\left[\mathrm{Si}(\mathrm{OH})_{6}\right]\left(\mathrm{CO}_{3}\right) \cdot 12\left(\mathrm{H}_{2} \mathrm{O}\right)$ thaumasite, $\mathrm{Ca}(\mathrm{SO})_{3} \cdot 0.5\left(\mathrm{H}_{2} \mathrm{O}\right)$ hannebachite, $\mathrm{NaCl}$ halite, $\mathrm{KCl}$ sylvite, $\mathrm{CaSO}_{4}$ anhydrite, $\mathrm{CaSO}_{4} \cdot 2\left(\mathrm{H}_{2} \mathrm{O}\right)$ Gypsum.

\begin{tabular}{|c|c|c|c|c|c|c|c|c|c|c|}
\hline \multirow[b]{2}{*}{ Sample } & \multirow[b]{2}{*}{$\begin{array}{c}\text { Wee } \\
\text { ks }\end{array}$} & \multicolumn{9}{|c|}{ Phase } \\
\hline & & $\begin{array}{l}\mathrm{Si} \\
\mathrm{O}_{2}\end{array}$ & $\begin{array}{l}\mathrm{K} \\
\mathrm{Cl}\end{array}$ & $\begin{array}{l}\mathrm{Na} \\
\mathrm{Cl}\end{array}$ & $\begin{array}{c}\mathrm{CaC} \\
\mathrm{O}_{3}\end{array}$ & $\begin{array}{c}\mu- \\
\mathrm{CaC} \\
\mathrm{O}_{3}\end{array}$ & $\begin{array}{c}\mathrm{Ca}_{3}\left(\mathrm{SO}_{4}\right)\left[\mathrm{Si}(\mathrm{OH})_{6}\right]\left(\mathrm{CO}_{3}\right) \\
12\left(\mathrm{H}_{2} \mathrm{O}\right)\end{array}$ & $\begin{array}{c}\mathrm{CaSO}_{4} \cdot 2(\mathrm{H} \\
2 \mathrm{O})\end{array}$ & $\begin{array}{c}\mathrm{CaS} \\
\mathrm{O}_{4}\end{array}$ & $\begin{array}{c}\mathrm{Ca}(\mathrm{SO})_{3} \cdot 0.5( \\
\left.\mathrm{H}_{2} \mathrm{O}\right)\end{array}$ \\
\hline \multirow{5}{*}{$\begin{array}{c}\text { Refere } \\
\text { nce }\end{array}$} & 5 & $\checkmark$ & & $\checkmark$ & $\checkmark$ & & & $\checkmark$ & $\checkmark$ & $\checkmark$ \\
\hline & 6 & $\checkmark$ & & & $\checkmark$ & & $\checkmark$ & $\checkmark$ & $\checkmark$ & $\checkmark$ \\
\hline & 7 & $\checkmark$ & $\checkmark$ & $\checkmark$ & $\checkmark$ & & $\checkmark$ & $\checkmark$ & $\checkmark$ & $\checkmark$ \\
\hline & 8 & $\checkmark$ & & & $\checkmark$ & & $\checkmark$ & $\checkmark$ & $\checkmark$ & $\checkmark$ \\
\hline & 13 & $\checkmark$ & & $\checkmark$ & $\checkmark$ & & & $\checkmark$ & $\checkmark$ & $\checkmark$ \\
\hline \multirow{5}{*}{$\begin{array}{c}\text { CR } \\
\text { sample } \\
\text { A }\end{array}$} & 5 & $\checkmark$ & $\checkmark$ & $\checkmark$ & $\checkmark$ & & $\checkmark$ & & & \\
\hline & 6 & $\checkmark$ & $\checkmark$ & $\checkmark$ & $\checkmark$ & & $\checkmark$ & & & \\
\hline & 7 & $\checkmark$ & $\checkmark$ & $\checkmark$ & $\checkmark$ & & $\checkmark$ & & & \\
\hline & 8 & $\checkmark$ & $\checkmark$ & & $\checkmark$ & & $\checkmark$ & & $\checkmark$ & \\
\hline & 13 & $\checkmark$ & & & $\checkmark$ & $\checkmark$ & & $\checkmark$ & & \\
\hline \multirow{5}{*}{$\begin{array}{c}\text { CR } \\
\text { sample } \\
\text { B }\end{array}$} & 5 & $\checkmark$ & $\checkmark$ & & $\checkmark$ & & $\checkmark$ & & & \\
\hline & 6 & $\checkmark$ & $\checkmark$ & $\checkmark$ & $\checkmark$ & & $\checkmark$ & & & \\
\hline & 7 & $\checkmark$ & $\checkmark$ & $\checkmark$ & $\checkmark$ & & $\checkmark$ & & & \\
\hline & 8 & $\checkmark$ & $\checkmark$ & $\checkmark$ & $\checkmark$ & & $\checkmark$ & & & \\
\hline & 13 & $\checkmark$ & & & $\checkmark$ & $\checkmark$ & & $\checkmark$ & & \\
\hline \multirow{5}{*}{$\begin{array}{c}\text { CR } \\
\text { sample } \\
\text { C }\end{array}$} & 5 & $\checkmark$ & & $\checkmark$ & $\checkmark$ & & $\checkmark$ & & & \\
\hline & 6 & $\checkmark$ & $\checkmark$ & & $\checkmark$ & & $\checkmark$ & & & \\
\hline & 7 & $\checkmark$ & $\checkmark$ & $\checkmark$ & $\checkmark$ & & $\checkmark$ & & & \\
\hline & 8 & $\checkmark$ & & $\checkmark$ & $\checkmark$ & $\checkmark$ & $\checkmark$ & $\checkmark$ & & \\
\hline & 13 & $\checkmark$ & & & $\checkmark$ & $\checkmark$ & & $\checkmark$ & & \\
\hline CR & 5 & $\checkmark$ & $\checkmark$ & & $\checkmark$ & & $\checkmark$ & & & \\
\hline
\end{tabular}




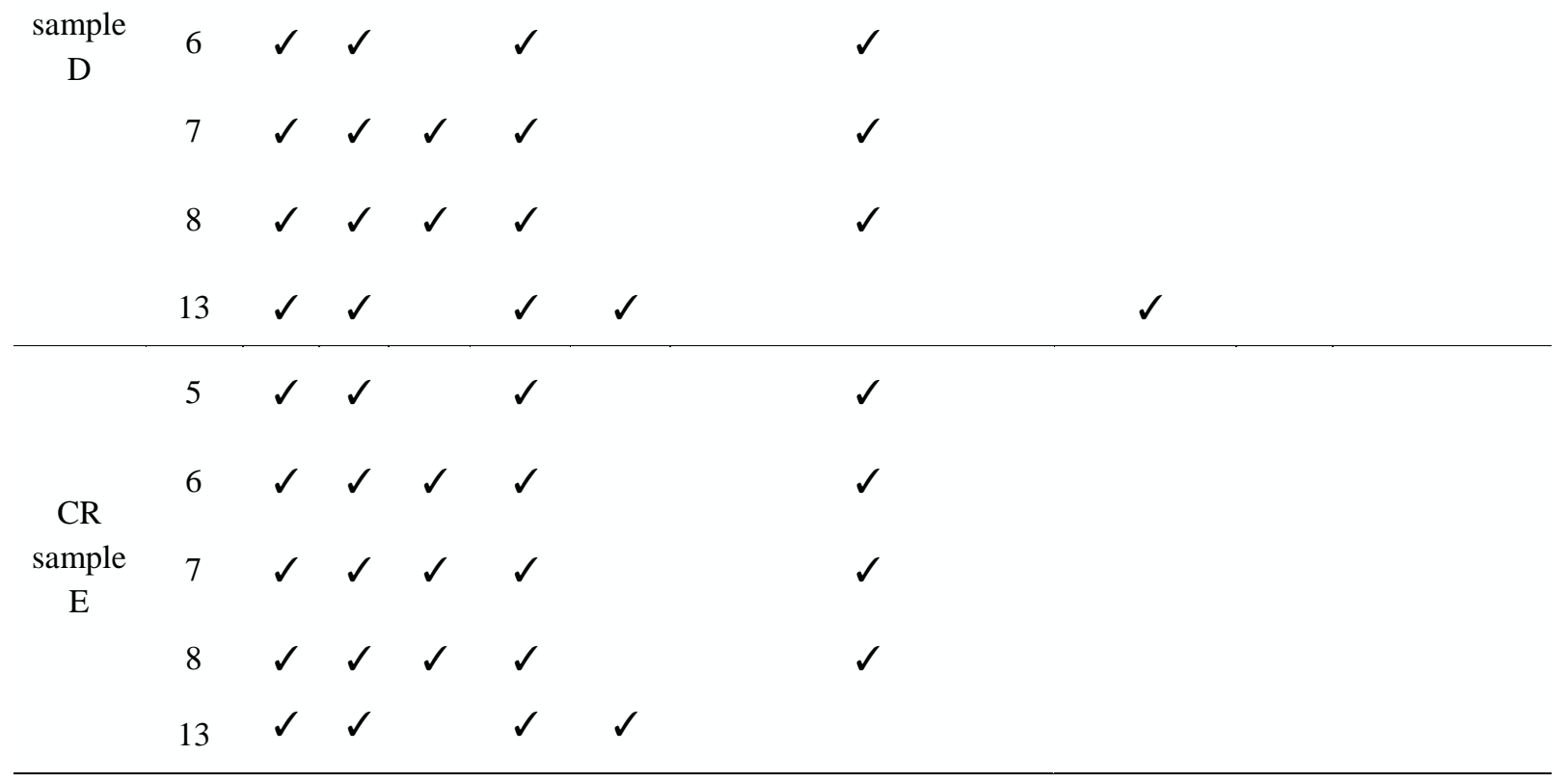

22 


\section{Table 5}

TGA-analyzed weight loss (\%) of all CR samples in three selected temperature ranges.

\begin{tabular}{ccccccc}
$\begin{array}{c}\text { Temperature range } \\
\left({ }^{\circ} \mathrm{C}\right)\end{array}$ & Reference & CR Sample A & CR Sample B & CR Sample C & CR Sample D & CR Sample E \\
\hline $550-680$ & 10.2 & 11.6 & 9.5 & 10.7 & 11.4 & 11.4 \\
$680-780$ & 1.3 & 1.5 & 1.2 & 1.3 & 1.4 & 2.2 \\
$780-990$ & 7.4 & 8.6 & 10.5 & 9.7 & 8.7 & 11.8 \\
TOTAL & 18.9 & 21.7 & 21.2 & 21.7 & 21.5 & 25.5 \\
\hline
\end{tabular}




\section{Figure captions}

Fig. 1 Graphical representation of the data reported in Table 1 and 2, for easier comparison and for easier identification of the enrichment due to combustion. A1, B1, C1, D1, E1 refers to data of corresponding samples reported in Table 1. A2, B2, C2, D2, E2 refers to data of corresponding samples reported in Table 2.

Fig. 2 XRD patterns collected on all wood pellet ashes. * Calcite $\left(\mathrm{CaCO}_{3}\right)$, - Calcium oxide $(\mathrm{CaO}), \circ$ Magnesium oxide $(\mathrm{MgO})$, $\star$ Potassium Calcium Carbonate $\left[\mathrm{K}_{2} \mathrm{Ca}\left(\mathrm{CO}_{3}\right)_{2}\right]$, Q Quartz $\left(\mathrm{SiO}_{2}\right)$, x Calcium Phosphate Hydroxide $\left[\mathrm{Ca}_{5}\left(\mathrm{PO}_{4}\right)_{3}(\mathrm{OH})\right], \diamond$ Calcium Manganese Oxide $\left(\mathrm{Ca}_{2} \mathrm{Mn}_{2} \mathrm{O}_{5}\right)$, e Sylvite $(\mathrm{KCl})$, ‡ Potassium sulfate $\left(\mathrm{K}_{2} \mathrm{~S}_{2} \mathrm{O}_{7}\right)$.

Fig. 3 Results of leaching tests for $\mathrm{Pb}$ and $\mathrm{Zn}$, made on samples treated with the COSMOS-RICE procedure and stabilized by using wood pellet ashes (A, B, C, D, and E). The data, that are obtained at different weeks after the stabilization (week 5, 6, 7, and 8), are reported in Table 3.

Fig. 4 XRD patterns collected on all samples obtained by treating MSWI fly ash with different wood pellet ashes by COSMOS-RICE procedure. * Calcite $\left(\mathrm{CaCO}_{3}\right),+$ Anhydrite $\left(\mathrm{CaSO}_{4}\right), \boldsymbol{Q}$ Quartz $\left(\mathrm{SiO}_{2}\right), \Delta \mathrm{Gypsum}$ $\left(\mathrm{CaSO}_{4} \cdot 2 \mathrm{H}_{2} \mathrm{O}\right)$, $\varepsilon$ Hannebachite $\left[2 \mathrm{CaSO}_{3} \cdot\left(\mathrm{H}_{2} \mathrm{O}\right)\right]$, $\Theta$ Thaumasite $\mathrm{Ca}_{3}\left(\mathrm{SO}_{4}\right)\left[\mathrm{Si}(\mathrm{OH})_{6}\right]\left(\mathrm{CO}_{3}\right) \cdot 12\left(\mathrm{H}_{2} \mathrm{O}\right)$, e Sylvite $(\mathrm{KCl}), \Sigma$ Halite $(\mathrm{NaCl}), \square$ Cristobalite $\mathrm{SiO}_{2}$.

Fig. 5 (a) DTG diagrams obtained on all COSMOS-RICE samples and (b) DTG data and results of mass spectroscopy $\left(\mathrm{MW}=18-\mathrm{H}_{2} \mathrm{O}, \mathrm{MW}=44-\mathrm{CO}_{2}\right.$ and $\left.\mathrm{MW}=64-\mathrm{SO}_{2}\right)$ determined for CR reference sample. 